\title{
Pharmacologically-active mediators of hypersensitivity reactions in the blood of lepromatous patients with erythema nodosum leprosum
}

\author{
K SAHA ${ }^{*} \dagger \&$ S C LAHIRI \\ $\dagger$ Department of Bacteriology, Govind Ballabh Pant Hospital, \\ New Delhi-110002, India; \$Department of Pharmacology, School \\ of Tropical Medicine, Calcutta, India
}

Received for publication 9 March 1981

\begin{abstract}
Summary A bioassay technique was employed to study the mediators of hypersensitivity reactions (MHR) in the blood of 9 control subjects and 20 borderline and polar lepromatous patients including 8 patients with erythema nodosum leprosum (ENL). MHR were isolated from blood and studied on virgin rat uterus following the technique originally described by Brocklehurst. The contractions of uterus were recorded, compared with a stock bradykinin solution which was taken as the reference standard and the levels of MHR were expressed as ng bradykinin equivalent $1 \mathrm{ml}$ blood. The mean level of MHR in lepromatous patients without ENL was $6.69 \mathrm{ng}$ bradykinin equivalent $1 \mathrm{ml}$ blood, but was significantly elevated in patients with ENL (18.09 ng bradykinin equivalent $1 \mathrm{ml}$ ). It was postulated that during the attack of ENL, Mycobacterium leprae or its broken products were released in the circulation containing high levels of antimycobacterial antibodies and thereby triggered the formation of circulatory immune complexes (CIC), activation of complement, deposition of $\mathrm{CIC}$ in various tissues and release of pharmacologically-active mediators of hypersensitivity reactions.
\end{abstract}

\section{Introduction}

A number of patients with lepromatous leprosy having high bacilliary load suffer from erythema nodosum leprosum (ENL). Some authors have advanced evidences as to the involvement of immune complexes in the pathogenesis of ENL, since deposits of immunoglobulin and complement have been identified in skin lesions ${ }^{1}$ and vessel walls. ${ }^{2}$ Recently bacilli, morphologically resembling

${ }^{*}$ Correspondence: to Dr K Saha. 


\section{$316 \quad K$ Saha and $S$ C Lahiri}

Mycobacterium leprae along with IgG, IgM, IgA and C3 were detected in the circulatory immune complexes (CIC). CICs were separated from the sera of polar and borderline lepromatous patients with or without ENL by the simplified polyethylene glycol technique. ${ }^{3}$ Most immune complexes, that are formed in-vivo, can activate humoral enzyme systems, fix the first component of complement, $\mathrm{Cl}$, and initiate a sequence leading to the formation of anaphylotoxin, a histamine-releasing substance, and a trimolecular complement factor, C567, which is chemotactic for polymorphonuclear leucocytes. Proteolytic enzymes released by the polymorphs also damage adjacent structures. ${ }^{4}$ In the kinin-forming system, they can form kinins by splitting its precursor, kininogen. This occurs through the activation of the Hageman (XII) factor of the coagulation system which initiates clot formation. ${ }^{5}$ In this preliminary communication we have turned our attention to the study of the pharmacologicallyactive mediators of hypersensitivity reaction (MHR) in the blood of lepromatous patients with or without ENL and have compared their levels with normal subjects.

\section{Materials and methods}

\section{HUMAN MATERIALS}

Twenty polar and borderline lepromatous patients including 11 cases with ENL from a leprosy village at Faridabad near Delhi and 9 normal subjects formed the basis of the study. In the patient group there were only 4 females. The diagnosis was based on clinical history, physical findings, lepromin test with armadillo-derived lepromin (WHO) and skin biopsy. ${ }^{6}$ Since our leprosy patients were of lower socio-economic status, our control group were also selected from the identical section of the society and their age and sex were matched with the patient group. All patients were on standard dapsone chemotherapy.

\section{COLLECTION OF BLOOD SAMPLES}

The procedure described by Brocklehurst ${ }^{7}$ was followed. Briefly, one volume of blood $(5 \mathrm{ml})$ was collected in a cold plastic syringe from the patient or control subject by venepuncture with minimum trauma and then forcibly squirted in a plastic vial containing 4 volumes $(20 \mathrm{ml})$ of chilled ethanol with vigorous mixing. Formation of large clumps was thus avoided. Thereafter the mixtures were kept for $4 \mathrm{~h}$, centrifuged, precipitates discarded and the supernatant stored at $-20^{\circ} \mathrm{C}$ in stoppered plastic containers for assay of the pharmacologically-active substances.

\section{PURIFICATION OF TEST SAMPLES TO REMOVE INTERFERING SUBSTANCES}

The alcohol extracts, besides kinins, also contained potassium from erythro- 
cytes, some $5 \mathrm{HT}$ fro $\mathrm{m}$ platelets and catechol amines. To remove these interfering substances, the supernatants were boiled to remove ethanol completely, dilute $\mathrm{HCl}(\mathrm{pH} \mathrm{1.5)}$ added, saturated with $\mathrm{NaCl}$, extracted twice with $n$-butanol, butanol evaporated, shaken with warm de Jalon solution and assayed for the pharmacologically-active substances. ${ }^{7}$

ESTIMATION OF THE PHARMACOLOGICALLY-ACTIVE MEDIATORS OF HYPERSENSITIVITY REACTIONS

Stilboestrol ( $1 \mathrm{mg} / \mathrm{kg}$ body weight) was injected subcutaneously in a virgin rat weighing about $120 \mathrm{~g}$. After $24 \mathrm{~h}$, the rat was sacrificed, the uterus was removed, and kept in de Jalon's solution at $-27^{\circ} \mathrm{C}-29^{\circ} \mathrm{C}$. The uterus was mounted in a $5-\mathrm{ml}$ tissue bath and the contractions of the uterus were recorded first with a standard stock bradykinin solution $(100 \mathrm{ng} / \mathrm{ml})$ and then with the test samples. The contractions of the uterus following the addition of the test samples were compared with the contraction due to the standard solution of bradykinin and the levels of the pharmacologically-active substances in the test samples were expressed as a ng bradykinin equivalent $1 \mathrm{ml}$ blood. The sensitivity of the assay of bradykinin varied from $200,500 \mathrm{pg} 1 \mathrm{ml}$. Recovery experiments showed recovery of bradykinin of the order of $70-90 \%$.

\section{Results}

The virgin rat uterus preparation which has been employed as our assay system is readily stimulated to contract by many substances other than plasma kinins. ${ }^{8}$

The blood levels of the pharmacologically-active substances in the controls and patients have been shown in Table 1. The mean level in the patients without ENL was $6.69 \mathrm{ng}$ bradykinin equivalent $1 \mathrm{ml}$, which was not significantly different from that $(4.77 \mathrm{ng}$ bradykinin equivalent $1 \mathrm{ml})$ in the controls. However, the average level (18.08 $\mathrm{ng}$ bradykinin equivalent $1 \mathrm{ml}$ ) in the patients with ENL was significantly higher than that in the controls as well as patients without ENL (Table 2).

\section{Discussion}

The virgin rat uterus assay technique, employed in the present study, not only detects bradykinin, but also responds to $5 \mathrm{HT}$ and prostaglandins (E1, E2, F $2 \alpha) .{ }^{8}$ These substances would make the usual assay on the rat uterus inaccurate. Thus the responses of the rat uterus observed by the addition of our test samples is most likely due to the kinins and/or prostaglandins present in the samples. However the surest method to characterize bradykinin in a test sample is to inactivate the polypeptide by incubation with chymotrypsin. Further if the uterine contraction is due to the polypeptide, the characterization may be further narrowed by showing that it will cause relaxation of the rat 
Table 1. Blood levels of the pharmacologically-active substances in normal subjects and lepromatous subjects

\begin{tabular}{|c|c|c|c|}
\hline \multirow[b]{2}{*}{ Serial No. } & \multirow[b]{2}{*}{ Type of subjects } & \multirow[b]{2}{*}{ ENL } & \multirow{2}{*}{$\begin{array}{l}\text { Levels of the pharmacologically- } \\
\text { active substances } \\
\text { ng bradykinin equivalent } / \mathrm{ml} \text { blood }\end{array}$} \\
\hline & & & \\
\hline 1 & Control & & 2.0 \\
\hline 2 & Control & & 4.5 \\
\hline 3 & Control & & 8.3 \\
\hline 4 & Control & & 6.0 \\
\hline 5 & Control & & 5.1 \\
\hline 6 & Control & & 3.0 \\
\hline 7 & Control & & 5.0 \\
\hline 8 & Control & & $<2.8^{*}$ \\
\hline 9 & Control & & 6.3 \\
\hline 10 & Leprosy & + & 7.3 \\
\hline 11 & Leprosy & - & $<3.2^{*}$ \\
\hline 12 & Leprosy & - & 11.9 \\
\hline 13 & Leprosy & + & 32.3 \\
\hline 14 & Leprosy & + & 6.8 \\
\hline 15 & Leprosy & - & 7.6 \\
\hline 16 & Leprosy & + & 12.6 \\
\hline 17 & Leprosy & + & 40.0 \\
\hline 18 & Leprosy & - & $<3.8^{*}$ \\
\hline 19 & Leprosy & + & 16.2 \\
\hline 20 & Leprosy & - & 10.9 \\
\hline 21 & Leprosy & + & 36.8 \\
\hline 22 & Leprosy & + & 28.6 \\
\hline 23 & Leprosy & + & $<4.3^{*}$ \\
\hline 24 & Leprosy & - & 6.8 \\
\hline 25 & Leprosy & + & 14.6 \\
\hline 26 & Leprosy & + & 8.6 \\
\hline 27 & Leprosy & - & $<2.9^{*}$ \\
\hline 28 & Leprosy & - & 3.5 \\
\hline 29 & Leprosy & + & 9.3 \\
\hline
\end{tabular}

${ }^{*}$ The minimum sensitivity varied from experiment to experiment.

duodenum. ${ }^{8}$ We in our present study have not performed these 2 control experiments. Thus one may precisely conclude that the observed rat uterus contraction by the samples taken from the lepromatous patients might be either due to the presence of kinins, or prostaglandins or both.

The release of bradykinin from mast cells has recently been demonstrated. ${ }^{9}$ Kumar et al. ${ }^{10}$ have demonstrated in leprosy patients an appreciable alteration in the morphology of mast cells and significant rises of serotonin and histamine as compared to the controls. However, they had not studied the bradykinin or prostaglandin levels during such an event. In man, bradykinin causes slow, sustained contraction of smooth muscles, increased vascular permeability, increased secretion of mucous glands and stimulation of pain fibres. Thus, 
Table 2. Mean levels of the pharmacologically-active substances in the blood of normal subjects and leprosy patients

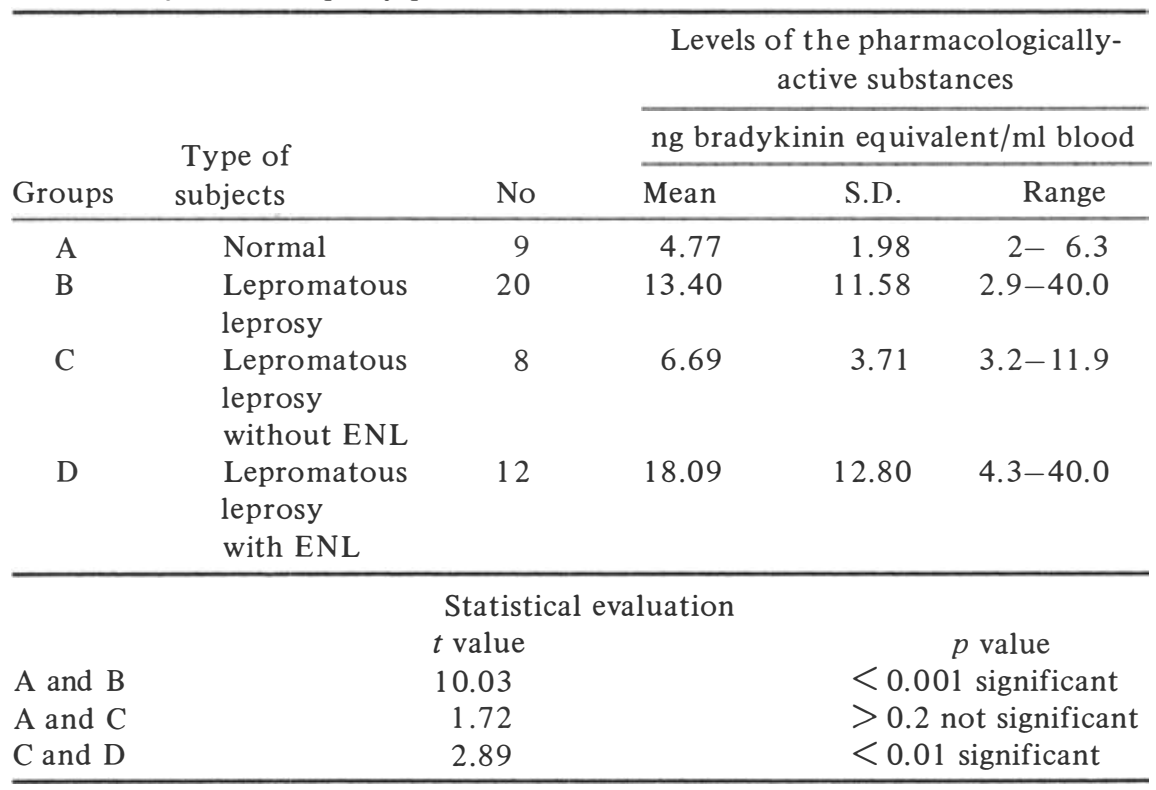

bradykinin could be responsible for the painful swelling and nodule formation during ENL episodes. Prostaglandins, which on the other hand comprise a number of naturally occurring aliphatic acids with a variety of biologic activities including increased permeability and dilation of capillaries, smooth muscle contraction and alteration in the pain threshold ${ }^{11}$ could also be released during lepra reactions. Bioassay on gerbil colon and chick rectum and radioimmunoassay of polypeptides may distinguish between kinins and prostaglandins. ${ }^{8}$

\section{References}

1 Wemembu SNC, Turk JL, Waters MFR, Rees RJW. Erythema nodosum leprosum: A clinical manifestation of the Arthus phenomenon. Lancet, 1969; ii: 933.

2 Waters MFR, Turk JL, Wemembu SNC. Mechanisms of reactions in leprosy. Int J Lep, 1971, 39: 417.

${ }^{3}$ Chakrabarty AK, Saha K, Prakash N. Detection of M. leprae in immune complex-enriched fraction after precipitation with polyethylene glycol of sera from lepromatous patients. Abstract. Fourth International Congress of Immunology. Paris 1980, Theme No 18, Workshop No 18.2.

${ }^{4}$ Cream JJ. Immune complex diseases. Br J Hosp Med, 1973; 9: 8.

5 NIAID Task Force Report (1979). The amplifying systems. In: Asthma and the Other Allergic Disease. NIH publication No 79-387, May, 1979. p. 55-104.

6 Ridley DS, Jopling, WH. Classification of leprosy according to immunity. A five group system. Int J Lep, 1961; 34: 255. 


\section{$320 \quad K$ Saina and $S$ C Lahiri}

${ }^{7}$ Brocklehurst WE. Kinin and kinin-forming enzymes in anaphylaxis. In: Austen KF, Becker EL, (eds), Biochemistry of the Acute Allergic Reactions, Oxford: Blackwell Scientific Publications: 1968; p. 297.

${ }^{8}$ Brocklehurst WE. The assay of mediators in hypersensitivity reactions. In: Weir DM (ed), Handbook of Experimental Immunology, Oxford: Blackwell Scientific Publications, 2nd ed, 1973; p. 43.1.

9 Frick OL. Immediate hypersensitivity. In: Fudenburg HH, Stites DP, Caldwell JL, Wells JV, (eds), Basic and Clinical Immunology. Los Altos. California; 1976; Lange Medical Publication. p. 204-24.

10 Kumar R, Vaidya MC, Belarkar BR. Morphological changes in mast cells and levels of serotoxin and histamine in leprosy patients. XI International Leprosy Congress ( $A b$ stract). Mexico City 13-18 November, 1978.

11 Wells JV. Immune mechanism in tissue damage. In: Fundenberg HH, Stite DP, Caldwell JL, Well JV (eds), Basicand Clinical Immunology, Los Altos, California: Lange Medical Publication, 1976; p. 225-241. 